\title{
Evaluation of haptoglobin phenotype $0-0$ in cirrhotic and non-cirrhotic hospital populations ${ }^{1}$
}

MANIS NANDI, GEORGE P. LEWIS, HERSHEL JICK, DENNIS SLONE, SAMUEL SHAPIRO, AND VICTOR SISKIND

From the Divisions of Clinical Pharmacology, Lemuel Shattuck Hospital, Tufts University Medical School, and the Veterans Administration Hospital, Boston, Massachusetts, USA

SYNOPSIS The haptoglobin phenotypes of 3,332 individuals, consisting of 2,930 caucasians and 402 negroes living in the greater Boston area, were determined. Of these, 3,222 were hospitalized medical patients fully documented regarding diagnoses. One hundred and twentyeight of the total population studied were shown to exhibit starch gel anhaptoglobinaemia (3.7\%). Re-evaluation on acrylamide gel of $1180-0$ samples revealed that the majority ( $94 \%$ ) were derived from patients exhibiting hypohaptoglobinaemia rather than anhaptoglobinaemia.

Haptoglobins are $\alpha_{2}$ glycoproteins which form stable complexes with free haemoglobin (Polonovsky and Jayle, 1939 and 1940). Smithies (1955) using starch gel electrophoresis demonstrated three distinct serum haptoglobin phenotype patterns. These were designated 2-1, 2-2, and $1-1$, and are the expression of three genetypes produced by a single pair of allelomorphic genes (Smithies and Walker, 1956). Later, it was observed using the starch gel technique that sera from a small percentage $(<3 \%)$ of healthy adult caucasians exhibited a total absence (anhaptoglobinaemia) of serum haptoglobin proteins (Allison, Blumberg, and Ap Rees, 1958). Family studies have demonstrated that in some instances such a phenomenon can be explained on a genetic basis (Harris, Robson, and Siniscalco, 1958; Matsunaga, 1962).

Illnesses accompanied by intravascular haemolysis (Brus and Lewis, 1959; Owen, DeGruchy, and Smith, 1960; Reerink-Brongers, Prins, and Krijnen, 1962) and/or liver disease with hepatocellular dysfunction (Jayle and Boussier, 1955; Owen, MacKay, and Got, 1959) can result in hypohaptoglobinaemia which is characterized by a reduction of the serum haptoglobin to a

${ }^{1}$ This research was supported by clinical pharmacology training grant number HE 5616-05 from the National Heart Institute and in part by contract PH-43-67-1485, National Institute of General Medical Sciences. and Clinical Pharmacology Training Program no. 42, Veterans Administration, USA.

Request for reprints to be made to M.N., Clinical Pharmacology, Eoston V.A. Hospital, 150 South Huntington Avenue, Boston, Massachusetts 02130, USA.

Received for publication 16 February 1970 level below the accepted normal range of 40 to $180 \mathrm{mg} \%$, expressed as haemoglobin-binding capacity (Nyman, 1959; Bayani-Sioson, Lauch, Sutton, Neel, Horne, and Gershowitz, 1962). If depletion is severe (ie, haemoglobin-binding capacity of less than $20 \mathrm{mg} \%$ ) then electrophoresis on starch gel may show an apparent absence of haptoglobin-haemoglobin protein complexes (anhaptoglobinaemia). Such sera are classified 0-0 phenotype. By using either a freezedrying or ultrafiltration technique as a means of concentrating serum proteins, investigators (Whitten, 1961; Murray, Robinson, and Visnich, 1966) using starch gel have been able to determine the haptoglobin phenotype of apparent anhaptoglobinaemic sera. The true haptoglobin phenotype of most sera classified 0-0 (starch gel) can, however, be ascertained without prior concentration using an acrylamide gel electrophoresis technique (Nandi and Lewis, 1970). The present paper reports a study of the haptoglobin phenotype distribution within a hospital population and the result of a re-examination on acrylamide gel of 117 patients with the 0-0 starch gel haptoglobin phenotype classification.

\section{Clinical Material}

A comprehensive drug surveillance programme is at present being conducted in five Boston hospitals (Slone, Jick, Borda, Chalmers, Feinleib, 
Muench, Lipworth, Bellotti, and Gilman, 1966). Nurse monitors collect information concerning vital statistics (including admission and discharge diagnoses), drug experience, and the occurrence or not of adverse reaction on all patients entering certain general medical wards. This information is then stored on magnetic tape and is available for programmed analysis. As a part of this survey, a blood sample is collected from each patient so that a genetic profile can be defined (Slone, Gaetano, Lipworth, Shapiro, Lewis, and Jick, 1969). Determination of haptoglobin phenotype on starch gel electrophoresis is included among the battery of tests routinely performed. The excess serum left over following completion of genetic testing is frozen at $-25^{\circ} \mathrm{C}$ and is available for further study. Of 3,310 consecutive patients admitted to the monitored medical wards, 3,222 were fully documented regarding race, diagnosis, haptoglobin phenotype, and titre. Because of racial differences in haptoglobin phenotype distribution a division into caucasian and negro was made. These populations were then subdivided into cirrhotics and non-cirrhotics. 'Normal' sera from an additional 110 caucasians (LSH staff members) were used for control purposes.

\section{Methods}

\section{HAPTOGLOBIN PHENOTYPE}

Starch gel electrophoresis (Smithies, 1955)

Haptoglobin phenotyping was routinely carried out in batches of 15 samples at a time on a horizontal starch gel block $(10 \mathrm{~cm} \times 18.5 \mathrm{~cm} \times$ $0.25 \mathrm{~cm}$ ) in a Buchler tank. In order to provide an adequate level of haemoglobin-haptoglobin

\begin{tabular}{|c|c|c|c|c|}
\hline \multirow[t]{2}{*}{ Population } & \multicolumn{3}{|c|}{ Haptoglobin Phenotype } & \multirow[t]{2}{*}{ Total } \\
\hline & $2-1(\text { no. })^{1}$ & $2-2($ no.) & $1-1$ (no.) & \\
\hline \multirow[t]{2}{*}{$\begin{array}{l}\text { Caucasian } \\
\text { Normal }^{2} \\
\text { Non-cirrhotic } \\
\text { Cirrhotic }\end{array}$} & $\begin{array}{r}46(42) \\
1,146(47) \\
128(47)\end{array}$ & $\begin{array}{r}45(41) \\
938(38) \\
104(39)\end{array}$ & $\begin{array}{l}18 \\
358(15) \\
36(14)\end{array}$ & $\begin{array}{r}109 \\
2,442 \\
268\end{array}$ \\
\hline & \multicolumn{3}{|c|}{$x^{2}(4 \mathrm{df})=1.31, \mathrm{P}>0.85$} & \\
\hline \multirow[t]{2}{*}{$\begin{array}{l}\text { Negro } \\
\text { Non-cirrhotic } \\
\text { Cirrhotic }\end{array}$} & $\begin{array}{r}171(47) \\
11(42)\end{array}$ & $\begin{array}{r}86(24) \\
7(27)\end{array}$ & $\begin{array}{r}102(29) \\
8(31)\end{array}$ & $\begin{array}{r}359 \\
26\end{array}$ \\
\hline & \multicolumn{3}{|c|}{$x^{2}(2 \mathrm{df})=0.28, \mathrm{P}>0.85$} & \\
\hline $\begin{array}{l}\text { Caucasian } v \text { negro } \\
\text { (overall haptoglobin } \\
\text { phenotype distribution) }\end{array}$ & \multicolumn{3}{|c|}{$x^{2}(2 \mathrm{df})=59.6, \mathrm{P}<0.001$} & \\
\hline
\end{tabular}

Table I Distribution of haptoglobin phenotypes (starch gel) in caucasian and negro cirrhotic and noncirrhotic populations excluding those classified 0-0

${ }^{1}$ Figures in parentheses indicate percentages.

'Hospital staff (LSH). complex for phenotyping, one drop of a $400 \mathrm{mg} \%$ solution of free haemoglobin was added to 50 drops of each serum sample before introduction $\vec{b}$ into the gel in filter paper wicks (Lewis, Mac Lennan, and Miller, 1969). A continuous borate buffer system $(0.027 \mathrm{~m}$ for the gel and $0.30 \mathrm{~m}$ for the bridge) was used. Optimum migration was obtained using an electric current of $1.5 \mathrm{ma} / \mathrm{cm}$ width (complementary voltage 140). Electro phoresis was continued for 18 hours overnigh? after which the gel was cut into three slices (Lewis and Yudowitz, 1966). The top surfaces of the middle slice was flooded with $5 \% 0=$ tolidine in $90 \%$ acetic acid. After 10 minutes $\omega$ colour development was induced by washing the gel surface with $1 \mathrm{vol} \%$ solution of hydroger peroxide. Optimal clarity and colour intensity ofw phenotype patterns occurs within 15 minutes.

Acrylamide gel

A two-phase horizontal acrylamide gel system was? used (Nandi and Lewis, 1970).

\section{Results}

Table I shows the distribution of haptoglobins phenotypes (starch gel) excluding those categorized as $\mathbf{0 - 0}$ in caucasian and negropopulations? A significant difference exists in the distribution of phenotypes when an overall comparison isu made between caucasians and negroes $(\mathrm{P}<0.001)$ in that there is an excess of $1-1$ and a deficiency of 2-2 phenotype in the negro population. In? contrast, no significant difference emerges when caucasian normals are compared with eithe caucasian non-cirrhotics or cirrhotics. Again cirrhotic and non-cirrhotic negroes have similano patterns of distribution.

Table II gives the incidence of $0-0$ (starch gel ${ }^{3}$. phenotype pattern associated with the popula tions listed in Table I. A significant excess of patients with the 0-0 phenotype occurs in both the caucasian and negro cirrhotic groups.

Table III lists the principal diagnoses asso을 ciated with the 127 patients exhibiting the $0-0$. pattern on starch gel electrophoresis. Fifty-five of the 110 caucasians had a diagnosis on dis $N$ charge of cirrhosis of the liver. Of the 55 caucasiant non-cirrhotics, 17 were described as either alcoholic or having acute hepatitis. Four of the 17 negroes had cirrhosis of liver, three of acute् or chronic alcoholism, and four of sickle celp? anaemia.

Table IV shows the true haptoglobin phenotype? distribution as revealed by acrylamide gel of 118 sera samples categorized as $0-0$ on starch gel. One 'normal' and six of the 50 caucasiancirrhotics remained $0-0$ following this examination. In contrast, none of the 51 caucasian non? cirrhotics with an 0-0 starch gel pattern remainest so following re-examination. Comparison betweet 


\begin{tabular}{|c|c|c|c|}
\hline \multirow[t]{2}{*}{ Population } & \multicolumn{2}{|c|}{ Haptoglobin Phenotype } & \multirow[t]{2}{*}{ Total } \\
\hline & $0-0(\text { no. })^{1}$ & Others (no.) & \\
\hline $\begin{array}{l}\text { Caucasian } \\
\text { Normal } \\
\text { Non-cirrhotic } \\
\text { Cirrhotic }\end{array}$ & $\begin{array}{l}1(0.9) \\
55(2 \cdot 2) \\
55(16 \cdot 9)\end{array}$ & $\begin{array}{r}109(99 \cdot 1) \\
2,442(97 \cdot 8) \\
268(83 \cdot 1)\end{array}$ & $\begin{array}{r}110 \\
2,497 \\
323\end{array}$ \\
\hline $\begin{array}{l}0-0 v \text { others } \\
\text { Normal } v \text { non-cirrhotic } \\
\text { Normal } v \text { cirrhotic } \\
\text { Non-cirrhotic } v \text { cirrhotic }\end{array}$ & \multicolumn{2}{|c|}{$\begin{array}{l}x^{2}(2 \mathrm{df})=175 \cdot 1, \quad \text { P }<0.001 \\
x^{2}(1 \mathrm{df})=0.34, \quad \text { P }>0.5 \\
\chi^{2}(1 \mathrm{df})=17.5, \quad \text { P }<0.01 \\
x^{2}(1 \mathrm{df})=163.8, \text { P }<0.001\end{array}$} & \\
\hline $\begin{array}{l}\text { Negro } \\
\text { Non-cirrhotic } \\
\text { Cirrhotic }\end{array}$ & $\begin{array}{c}13(3 \cdot 5) \\
4(12 \cdot 3)\end{array}$ & $\begin{array}{c}359(96 \cdot 5) \\
26(87 \cdot 7)\end{array}$ & $\begin{array}{c}372 \\
30\end{array}$ \\
\hline $\begin{array}{l}\text { Non-cirrhotic } v \text { cirrhotic } \\
\text { (Fisher exact test) }\end{array}$ & \multicolumn{2}{|c|}{$P=0.03($ one-tailed test $)$} & \\
\hline
\end{tabular}

Table II Distribution of haptoglobin 0-0 phenotype (starch gel) in caucasian and negro non-cirrhotic and cirrhotic populations

${ }^{1}$ Figures in parentheses indicate percentages.

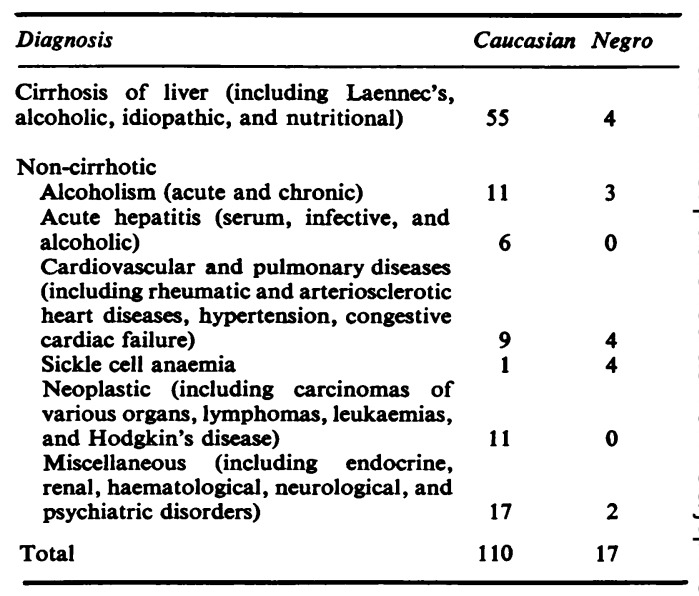

Table III Distribution of 127 patients classified haptoglobin phenotype 0-0 on starch gel electrophoresis of within several broad diagnositc categories

\begin{tabular}{|c|c|c|c|c|c|c|c|c|}
\hline \multirow[t]{3}{*}{ Population } & \multirow[t]{3}{*}{ Total } & \multicolumn{7}{|c|}{ Haptoglobin Phenotype (\%) } \\
\hline & & \multicolumn{2}{|l|}{$2-1$} & \multicolumn{2}{|l|}{$2-2$} & \multicolumn{2}{|l|}{$1-1$} & \multirow{2}{*}{$\frac{0-0}{\text { Observed }}$} \\
\hline & & Observed & Expected $^{1}$ & Observed & Expected $^{1}$ & Observed & Expected $^{1}$ & \\
\hline \multirow[t]{2}{*}{$\begin{array}{l}\text { Caucasian } \\
\text { Normal } \\
\text { Non-cirrhotic } \\
\text { Cirrhotic }\end{array}$} & $\begin{array}{r}1 \\
51 \\
50\end{array}$ & $\begin{array}{l}0 \\
19(37) \\
17(39)\end{array}$ & $\begin{array}{l}23 \cdot 9 \\
20 \cdot 6\end{array}$ & $\begin{array}{c}0 \\
30(59) \\
22(50)\end{array}$ & $\begin{array}{l}19 \cdot 7 \\
17 \cdot 0\end{array}$ & $\begin{array}{l}0 \\
2(4) \\
5(11)\end{array}$ & $\begin{array}{l}7 \cdot 4 \\
6 \cdot 4\end{array}$ & $\begin{array}{l}1 \\
0 \\
6\end{array}$ \\
\hline & & \multicolumn{7}{|c|}{$\begin{array}{l}\text { Non-cirrhotic (observed) } v \text { non-cirrhotic (expected) } x^{2}(2 \mathrm{df})=10.3 \\
\text { Cirrhotic (observed) } v \text { cirrhotic (expected) } \chi^{2}(2 \mathrm{df})=2.4\end{array}$} \\
\hline $\begin{array}{l}\text { Negro } \\
\text { Non-cirrhotic } \\
\text { Cirrhotic }\end{array}$ & $\begin{array}{r}12 \\
4\end{array}$ & $\begin{array}{l}5 \\
0\end{array}$ & $\begin{array}{l}5 \cdot 7 \\
1 \cdot 9\end{array}$ & $\begin{array}{l}7 \\
3\end{array}$ & $\begin{array}{l}2.9 \\
1.0\end{array}$ & $\begin{array}{l}0 \\
1\end{array}$ & $\begin{array}{l}3 \cdot 4 \\
1 \cdot 1\end{array}$ & $\begin{array}{l}\mathbf{0} \\
\mathbf{0}\end{array}$ \\
\hline
\end{tabular}

Table IV Haptoglobin phenotype distribution of sera designated $0-0$ on starch gel after re-evaluation on acrylamide gel

'Expected values based on non 0-0 distribution (for each group) of Table I

the observed distribution of the re-allocated samples and their expected distribution calculated from the distribution of haptoglobin phenotype in the non 0-0 phenotype population (Table I) reveals an excess of patients with 2-2 phenotype in both caucasian cirrhotic and noncirrhotic starch gel 0-0 samples. A comparison of the distribution of the re-evaluated $0-0$ haptoglobin phenotypes of negro cirrhotic and non-cirrhotic sera was not made because of the smallness of the sample sizes.

\section{Discussion}

The overall pattern of haptoglobin phenotype distribution in normal, non-cirrhotic, and cirrhotic caucasian populations living in the greater
Boston area were found to be identical when subjects with an 0-0 phenotype (starch gel) were excluded. Similarly, no significant difference in phenotype distribution emerged when negro? cirrhotics and non-cirrhotics were compared. N The differences in phenotype distribution between $N_{\mathcal{E}}$ caucasians and negroes reported by others wereo confirmed (Allison et al, 1958; Giblett, 1959; Allison and Barnicot, 1960). The incidence of apparent anhaptoglobinaemia (starch gel) in $\stackrel{\circ}{+}$ caucasian and negro cirrhotic populations $(17 \%$ and $12 \%$ ) was very much higher than that foundo in the respective non-cirrhotic populations $(2.2 \%$ and $3.5 \%)$.

Because of the relative insensitivity of the starch gel electrophoresis technique for haptoglobin phenotyping, it is possible for a serumo derived from a patient with a profound degrees of hypohaptoglobinaemia to be categorized 
'anhaptoglobinaemic'. Unfortunately, such a classification carries with it an inference of genetic amorphism.

Examination using acrylamide gel electrophoresis of 55 cirrhotic sera samples (51 caucasians and four negroes) exhibiting 0-0 phenotype pattern on starch gel shows that all but six were from patients with severe hypohaptoglobinaemia. The six 0-0 (acrylamide gel) sera were all from the caucasian cirrhotics.

The present study was confined to an examination of only one serum from each patient. The degree of hypohaptoglobinaemia in liver disease can vary from time to time, depending on the state of hepatic decompensation and the presence or not of either biliary obstruction or haemolysis (Kallai, Keler-Bačoka, Blažević, and Knežević, 1966). It would require the demonstration of persistent anhaptoglobinaemia on acrylamide gel over an extended period of time to give even presumptive evidence of genetic amorphism, particularly in those patients with diseases associated with hypohaptoglobinaemia. Such a feature, however, together with the demonstration of anhaptoglobinaemia in one or more healthy blood relative, would be of inestimable value in establishing the existence of true amorphism.

Sixty-eight patients (55 caucasian and 13 negroes) with $0-0$ classification on starch gel came from the non-cirrhotic population. Many of these had diseases associated with excessive red cell destruction (eg, sickle cell anaemia) or impaired liver function (eg, acute hepatitis, chronic and acute alcoholism). All such patients were shown to have a small quantity of haptoglobin protein in their sera thereby supporting the presence of hypohaptoglobinaemia rather than true anhaptoglobinaemia. One 'normal' subject exhibiting the 0-0 phenotype on starch gel remained so following examination on acrylamide gel. It is therefore possible that this individual carries the amorphic gene. Further investigation as suggested above, would be required to establish this point.

The distribution of haptoglobin phenotypes (acrylamide gel) of the starch gel 0-0 samples show an excess of phenotype 2-2. This finding is more marked when the caucasian non-cirrhotics are considered. This is in agreement with previous studies which have shown that patients with haptoglobin phenotype 2-2 are more liable to develop hypohaptoglobinaemia than those with 2-1 or 1-1 (Parker and Bearn, 1963; Sutton and Karp, 1964; Murray et al, 1966). Of particular interest, five patients with the sickle cell anaemia in our series (one caucasian and four negroes), although classified 0-0 on starch gel, could be phenotyped on acrylamide gel. Allison et al (1958) using starch gel showed an unusual distribution of haptoglobin phenotypes in an African population in Nigeria $(32.3 \%$ with phenotype $0-0 ; 53.5 \%, 1-1 ; 11.1 \%, 2-1$; and
$3.0 \%, 2-2)$. It has been suggested that the excess of 0-0 phenotypes found in this geographic areas is partly due to the presence of endemic malaria and sickle cell anaemia (Giblett, 1969). A furtherexamination of the sera from Africans with acs starch gel 0-0 phenotype pattern, using theo acrylamide gel technique, might give valuable information concerning the contribution madews by hypohaptoglobinaemia to this unusual phenotype distribution.

During our study, $92 \%$ of the starch gel $0-0^{\infty}$ phenotype samples were available for re- $\overrightarrow{0}$ examination on acrylamide gel. The information $\vec{\overrightarrow{ }}$ obtained allows a more accurate estimate to be made than hitherto concerning the incidence of anhaptoglobinaemia among the American caucasian and negro populations studied. Starch ge ${ }^{\omega}$ anhaptoglobinaemia has been reported to be present in $0-3 \%$ (Allison et al, 1958) of normale caucasians and in $3-5 \%$ of American negroeso (Giblett, 1969). We observed in a total caucasian? population of 2,930 (consisting primarily of the $z$ hospitalized patients) an incidence of acrylamide gel anhaptoglobinaemia of $0.24 \%$ (seven patients). It must be emphasized that six of these were patients with cirrhosis of the liver. Of the 402 American negroes studied, $4.2 \%$ (17) exhi- $\vec{\varphi}$ bited anhaptoglobinaemia on starch gel. Re-O evaluation on acrylamide gel of $94 \%$ (16) of these patients revealed the presence of hapto-globin proteins in every sample. The overallㅡㅡㅇ occurrence of acrylamide gel anhaptoglo-@ binaemia was, therefore, less than $0 \cdot 25 \%$. This $\bar{\Phi}$ study supports the premise that true genetic anhaptoglobinaemia is a rare phenomenon. Mosto sera classified 0-0 on starch gel are derived from patients with hypohaptoglobinaemia.

Mrs Maija Galins and Miss Linda Coughlin gave valuable technical assistance. Thanks areô also extended to the nurse monitors of Tufts $₹$ Unit of Clinical Pharmacology, Boston, for the윽 collection of clinical data and blood samples.

\section{References}

Allison, A. C., and Barnicot, N. A. (1960). Haptoglobins and transferrins in some East African peoples. Acta Genet.(Basel), $\sigma$ 10, 17-23.

Allison, A. C., Blumberg, B. S., and Ap Rees, W. (1958). Hapto globin types in British, Spanish Basque and Nigerian African populations. Nature (Lond.), 181, 824-825.

Bayani-Sioson, P. S., Louch, J., Sutton, H. E., Neel, J. V., Horne, S. L., and Gershowitz, H. (1962). Quantitative studies on the haptoglobin of apparently healthy adult male twins. Amer. J. hum. Genet., 14, 210-19.

Brus, I., and Lewis, S. M. (1959). The haptoglobin content of serum in haemolytic anaemia. Brit. J. Haemat., 5, 348-55.

Giblett, E. R. (1959). Haptoglobin types in American Negroes. 으 Nature (Lond.), 183, 192-193.

Giblett, E. R. (1969). Haptoglobin. In Genetic Markers in Human Blood, ch. 2, pp. 63-125. Davis, Philadelphia, $\mathrm{Pa}$.

Harris, H., Robson, E. B., and Siniscalco, M. (1958). AtypicalO segregation of haptoglobin types in man. Nature (Lond.), 182, 1324-5.

\section{.}


Jayle, M. F., and Boussier, G. (1955). Les séramucoids du sang leurs relations avec mucoprotàines de la substance fondamentale du tissu conjonctif. Exp. Ann. biochim. Med., 17, 157-172.

Kallai, L., Keler-Bačoka, M., Blaževič, K., and Kňezevič, S. (1966). The interpretation of haptoglobin values in the diagnosis of liver disease. Crastroenterologia (Basel), 105, 27-34.

Lewis, G. P., and Yudowitz, B. S. (1966). A simple method for slicing starch gels. J. clin. Path., 19, 521-523.

Lewis, G. P., MacLennan, W. J., and Miller, S. (1969). Loading starch gels using filter paper wicks. J. clin. Path., 22 242-243.

Matsunaga, E. (1962). An inert allele $\mathrm{Hp}^{\circ}$ at the $\mathrm{Hp}$ locus. Japan J. hum. Genet., 7, 133-135.

Murray, R. F., Jr., Robinson, J. C., and Visnich, S. (1966). Observations on the inheritance of hypohaptoglobinemia. Acta genet. (Basel), 16, 113-21.

Nandi, M., and Lewis, G. P. (1970). Thin layer acrylamide gel electrophoresis. J. clin. Path., 23, 727-729.

Nyman, M. (1959). Serum haptoglobin-methodological and. clinical studies. Scand. J. clin. Lab. Invest., 11, Suppl. 39.

Owen, J. A., DeGruchy, G. C., and Smith, H. (1960). Serum haptoglobins in haemolytic states. J. clin. Path., 13, 478-482.

Owen, J. A., Mackay, I. R., and Got, C. (1959). Serum haptoglobins in hepatobiliary disease. Brit. med. J., 2, 1454-1457.

Parker, W. C., and Bearn, A. G. (1963). Control gene mutation as a possible explanation of certain haptoglobin phenotypes. Amer. J. hum. Genet., 15, 159-81.
Polonovski, M., and Jayle, M. F. (1939). Peroxydases animales. Leur spécificité et leur rôle biologique. Bull. Soc. Chim. biol. (Paris), 21, 66-91.

Polonovski, M., and Jayle, M. F. (1940). Surla préparation d'une nouvelle fraction des protéines plasmatiques, l'haptoglobine. C.R. Acad. Sci. (Paris), 211, 517-519.

Reerink-Brongers, E. E., Prins, H. K., and Krijnen, H. W. (1962). Haptoglobin and increased haemolysis. Vox Sang (Basel), $\stackrel{\overrightarrow{+}}{+}$ 7, 619-31.

Slone, D., Gaetano, L. F., Lipworth, L., Shapiro, S., Lewis, G. P., and Jick, H. (1969). Computer analysis of epidemiologic data on effect of drugs on hospital patients. Publ. Hlth Rep. (Wash.), 84, 39-52.

Slone, D., Jick, H., Borda, I., Chalmers, T. C., Feinleib, M., \& Muench, H., Lipworth, L., Bellotti, C., and Gilman, B. Q (1966) Drug surveillance using nurse monitors. Lancet, 2, 901-903.

Smithies, O. (1955). Zone electrophoresis in starch gels: group variations in serum proteins of normal human adults. Biochem. J., 61, 629-641.

Smithies, O., and Walker, N. F. (1956). Notation for serumprotein groups and the genes controlling their inheritance. Nature (Lond.), 178, 694-695.

Sutton, H. E., and Karp, G. W., Jr. (1964). Variations in hetero- N zygous expression at the haptoglobin locus. Amer. J. hum. $\infty$ Genet., 16, 419-34.

Whitten, C. F. (1961). Studies on serum haptoglobins. Amer. J. O Dis. Childh., 102, 480-81. 